\title{
Perceived Risk on Consumer Online Shopping Behaviour
}

\author{
Endah Setya Octaviani ${ }^{\mathrm{a}}$, Hendra Gunawan ${ }^{\mathrm{b} *}$ \\ a Jurusan Manajemen Bisnis, Politeknik Negeri Batam, endahoctaviani@gmail.com, Indonesia \\ bJurusan Manajemen Bisnis, Politeknik Negeri Batam, hendra@ polibatam.ac.id, Indonesia
}

\begin{abstract}
This study aims to determine the effect of perveived risk on consumer online shopping behavior of fashion product. The significant difference presented are the product category, using the category of fashion product as the most demand category by consumers. Samples used are students in the field of accounting at universities. The result of this research are there is negative influence of perception of product risk to customer satisfaction and re-purchased intention. The perveived cost risk has no negative effect on satisfaction and re-purchased intention. Perception of individual risk do not have a negative effect on customer satisfaction and re-purchased intention.
\end{abstract}

Keywords: perceived risk, satisfaction, re-purchased intention, consumer behavior

\section{Introduction}

Along with the development of technology, shopping activities that can be done in various places such as shopping centers to make purchases or shopping goods or services online. This is caused by several factors one of which is the number of internet users are increasing. The survey conducted by Association of Internet Service Providers Indonesia (APJII) revealed that in 2016 the number of internet users in Indonesia is 132.7 million users or $51.5 \%$ of the total population of Indonesia. Based on the most visited content, internet users most often visit the online shop website for 82.2 million or $62 \%$.

Fashion products are the most frequently purchased or sought-after products in online purchases ( $\mathrm{Hu} \&$ Xie, 2014). The results of a survey conducted by Directorate General of Aptika revealed that in 2015 the category of fashion products was ranked as the most popular and frequently purchased item of $37.6 \%$, followed by the purchase of mobile products by $12.2 \%$. This is because fashion is one of the factors of fulfillment of basic needs, fashion is also a necessity for people to be able to look attractive in front of others.
Buying online becomes an interesting for consumers with various advantages such as ease and convenience. One of them is the ease in comparing goods and prices from one shop to another, convenient to be able to shopping anywhere. In addition to the convenience and convenience provided/ease and convenience, there are some barriers faced by consumers in online shopping, the trust between sellers and buyers are still thin, misuse of information, elusive website models or an elusive and the delivery of feared goods will not be up to date or damaged in deliveries that makes consumers cancel to do online transaction purchase.

The behavior of online purchasing is consumer behavior in searching, buying, using, evaluating and spending the desired products and services (Priansa, 2017). The intention of buying consumers can predict consumers' buying behavior (East, Wright, \& Vanhuele, 2013). According to Ajzen (1991) in Theory of Planned Behavior that consumer intentions can predict individual behavior. Intention is determined by attitudes toward behavior, subjective norms and perceptions of behavioral control. Attitudes are the result of consideration of the belief in the profit and loss of the behavior and consequences that will

*Corresponding author. E-mail: hendra@polibatam.ac.id 
occur, while the subjective norm is reinforced by one's beliefs and motivations.

According to Monsuwe, Dellaert, \& Ruyter (2004), privacy and security are related to trust factors because buying online can't see and check to be purchased directly. Risk perception is an uncertainty faced by consumers when they can not predict the consequences of purchasing decisions (Schiffman \& Wisenblit, 2015). Risk will arise if the consumer believes that there is a possibility of a wrong decision and the consequences of a wrong decision are considered significant. Dimensions on risk perceptions expressed by Naiyi (2004) are perceptions of product delivery risk, financial risk, loss of risk due to process and time, product performance risk, privacy and information.

Javadi et al. (2012) examines the factors that influence online shopping behavior by using sample online stores in Iran. This study shows that the financial risks and non-delivery of products has negative impact online shopping attitudes. Yue, Xiangbin, \& Weiguo (2015) also proves that the perception of product risk and individual anxiety negatively affect consumer behavior reinforced by the success factor of the information system as a control variable that is the quality of service and website quality that positively affect consumer behavior.

This research is a development of research (Yue, Xiangbin, \& Weiguo, 2015). The differences in this study with Yue, Xiangbin, \& Weiguo's (2015) research are as follows. First, use the fashion product category as the most searched product category in online purchases. The second difference, the sample used is the accounting students in. The last difference is the technique of sampling used is the technique of non probability sampling using purposive sampling approach method with the criteria that the respondents are active accounting students who have made online purchases on fashion products.

\section{Literature Review}

\section{Customer Satisfaction and Re-Purchase Intention}

Consumer purchasing behavior refers to the behavior that consumers display when searching, purchasing, using, evaluating and consuming products to meet their needs and wants (Priansa, 2017). Ajzen (1991) and Bhatnagar et al. (2000) states that the theory of action reason (TRA) and theory of behavior planning (TPB) shows that consumer attitudes and intentions can predict actual behavior. The expectation confirmation theory (ECT) reveals that hope and confirmation increase customer satisfaction and purchase intentions.

\section{Theory of Reasoned Action}

The theory of reasoned action is the intention of a person to conduct a behavior determining whether or not to do such behavior (Ajzen, 1991). Ajzen revealed there are two basic determinants to know the intention to perform or not to do certain behaviors, namely attitude and subjective norms. Attitudes are the result of consideration of beliefs about the profit and loss of behavior and consequences that will occur, while the norms are influenced by the beliefs and motivations of a person.

\section{Theory of Perceived Risk}

Bauer (1960) states that there are two risks of uncertainty and consequence. The perceived risk perception by consumers is the uncertainty felt by consumers in online shopping when consumers can not predict what consequences and losses will be experienced from their purchase decisions (Schiffman \& Wisenblit, 2015). Perceptions of risk used in this study are, perceptions of cost risk, perceived product risk and perceptions of individual anxiety risk.

\section{Perceived Cost Risk}

Perception of cost risk refers to the unnatural price and time spent in choosing. Compared to offline transactions, online purchases have negative characteristics of lack of contact, complexity in technology, etc. (Bhatnagar, Misra, \& Rao, 2000). Higher transaction costs, too much time spent in searching, comparing products and delivery periods will offset the benefits brought by online purchases. Consumer satisfaction will decrease resulting in lower repurchase intention.

H1a: Perceived cost risk has negative effects to consumer satisfaction.

HIb: Perceived cost risk has negative effects to repurchase intentions.

\section{Perceived Product Risk}

According to Lim (2003) product risk refers to the quality, performance and value of the product. Consumers hope to get good product service and meet 
the good quality so as to bring the satisfaction and willingness of the consumer to buy the product again because it has been in line with expectations. But in reality, the situation can not be promised. Lack of information and uncertainty about product performance decreases consumers' intention to buy back.

$\mathrm{H} 2 \mathrm{a}$ : Perceived product risk has negative effects to consumer satisfaction.

$\mathrm{H} 2 \mathrm{~b}$ : Perceived product risk has negative effects to repurchase intentions.

\section{Perceived Individual Risk}

Perceived individual risk refers to the negative psychological influences that consumers perceive when making online purchases. Consumers worry that purchased products are not in line with expectations (Bhatnagar, Misra, \& Rao, 2000). Naiyi (2004) states that perceived individual risk also refer to the occurrence of leakage of information such as phone numbers, email and other identity data.

H3a: Perceived individual anxiety risk has negative effect to consumer satisfaction.

$\mathrm{H} 3 \mathrm{~b}$ : Perceived individual anxiety risk has negative effects to repurchase intention.

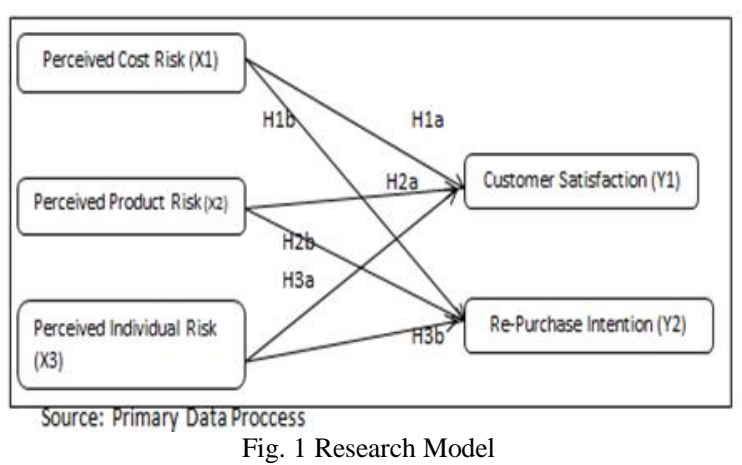

\section{Research Method}

The type data of this research is the interval data that has the value of classification, there is a sequence and distance. Sources of data of this study using primary data by distributing questionnaires to accounting students. This research uses quantitative research approach in conducting hypothesis testing.

The method used in this study using descriptive statistical test, validity test, reliability test, classical assumption test and simple linear analysis. A simple regression analysis model was chosen to determine the effect between the dependent variable and the independent variable. Independent variables in this study were perceived cost risk, perceived product risk and perceived of individual anxiety risk. Dependent variable in this research are consumer satisfaction and repurchase intention.

This study uses three steps in managing data that have been obtained from the respondents. Here are the stages of data processing: The first stage begins by checking the amount of data questionnaires returned to the author and completeness of the data on the contents of the questionnaire has been in accordance with the criteria samples performed. The second stage is to recover the data obtained. Hypothesis testing was done by using simple regression analysis. Prior to the analysis of the regression, the analysis of data that must be done is the descriptive statistical test and the classical assumption test.

\section{Results and Discussion}

The number of samples used in this study is 200 respondents. The first independent variables of cost perceived risk perception have a minimum value of 8 and a maximum of 15 . The average cost perceived risk is 11.89 with a standard deviation of 1.851 . The second independent variable that is the perception of product risk, has a minimum value of 3 and maximum 10 . Average product risk perception is 5.65 with a standard deviation of 1.344. The third dependent variable is the perception of an individual's anxiety risk has a minimum value of 8 and a maximum of 15 . The average perception of individual anxiety risk is 12.00 with a standard deviation of 1.768 . Variable in this research is consumer behavior consisting of consumer satisfaction and intention of buy back. Consumer satisfaction has a maximum value of 5 and minimum 2. Average consumer satisfaction is 3.90 with a standard deviation of 0.959 . The repurchase intention has a maximum value of 10 and a minimum of 4 . The average of repurchase intention is 7.87 with a standard deviation of 1.834 .

\begin{tabular}{lccccc}
\multicolumn{7}{c}{ Table 1 Statistic of Respondents } \\
\hline $\begin{array}{c}\text { Statistik } \\
\text { Deskriptif }\end{array}$ & $\begin{array}{c}\text { Perceived } \\
\text { Cost Risk }\end{array}$ & $\begin{array}{c}\text { Perceived } \\
\text { Product } \\
\text { Risk }\end{array}$ & $\begin{array}{c}\text { Perceived } \\
\text { Individual } \\
\text { Risk }\end{array}$ & $\begin{array}{c}\text { Customer } \\
\text { Satisfaction }\end{array}$ & $\begin{array}{c}\text { Re- } \\
\text { Purchase } \\
\text { Intention }\end{array}$ \\
\hline $\mathrm{N}$ & 200 & 200 & 200 & 200 & 200 \\
Mean & 11,89 & 5,65 & 12,00 & 3,90 & 7,87 \\
Std. Deviation & 1,851 & 1,344 & 1,768 & 0,959 & 1,834 \\
Minimum & 8 & 3 & 8 & 2 & 4 \\
Maximum & 15 & 10 & 15 & 5 & 10 \\
\hline
\end{tabular}


Hypothesis 1a proposed in this study states that the perception of cost risk negatively affect consumer satisfaction. Hypothesis is said to be supported if sig $<0.05$ and negative value.

Table 2 Hypothesis Test 1a

\begin{tabular}{|c|c|c|c|}
\hline & Hypothesis & B & Sig \\
\hline$\overline{\text { H1a. }}$ & $\begin{array}{l}\text { Perceived cost risk has negative effect } \\
\text { consumer satisfaction }\end{array}$ & 0.116 & 0.001 \\
\hline
\end{tabular}

The perception of cost risk is significantly positive to customer satisfaction. Hence hypothesis 1a is not supported because the regression coefficient has positive value. The regression equation can be written as follows:

$$
\mathrm{K}=2.528+0,116
$$

Hypothesis $1 \mathrm{~b}$ proposed in this study states that the perception of cost risk negatively affect the repurchase intention.

Table 3 Hypothesis Test $1 \mathrm{~b}$

\begin{tabular}{lll} 
Hypothesis & B & Sig \\
\hline
\end{tabular}

H1b. Perceived Cost risk has negative effects to $0.223 \quad 0.001$ repurchase intentions.

The perception of cost risk is significantly positive to the repurchase intention Hence hypothesis $1 \mathrm{a}$ is not supported because the regression coefficient has positive value. The regression equation can be written as follows:

$$
\mathrm{NP}=5.213+0.223
$$

Hypothesis 2a proposed in this study states that the perception of product risk negatively affect consumer satisfaction. Hypothesis is said to be supported if sig <0.05 and regression coefficient is negative.

Table 4 Hypothesis Test 2a

\begin{tabular}{llc}
\hline \multicolumn{1}{c}{ Hypothesis } & B & Sig \\
\hline H2a. Perceived product risk has negative effects & -0.149 & 0.003 \\
to consumer satisfaction
\end{tabular}

The perception of product risk is negatively negative to customer satisfaction. Hence hypothesis $2 \mathrm{a}$ is supported because it has sig value $<0.05$ is 0.003 and result of coefficient of regresi have negative value. The regression equation can be written as follows:

$$
\mathrm{K}=4.7480-0.149
$$

Hypothesis $2 \mathrm{~b}$ proposed in this study states that the perception of product risk negatively affect the intention of repurchase. Hypothesis is said to be supported if sig <0.05 and regression coefficient is negative.

Table 5 Hypothesis Test $2 b$

\begin{tabular}{lcc} 
Hipotesis & B & Sig \\
\hline duct risk has negative effects to & $-0,266$ & 0,006
\end{tabular}

H2b. Perceived product risk has negative effects to $-0,266 \quad 0,006$ repurchase intention

The perception of product risk is significantly negative to the repurchase intention. Hence hypothesis $2 \mathrm{~b}$ is supported because it has sig value $<0.05$ is 0.006 and result of coefficient of regresi have negative value. The regression equation can be written as follows:

$$
\mathrm{NP}=9.365-0.266
$$

Hypothesis 3a proposed in this study states that the perception of individual anxiety risk have negative effect on consumer satisfaction. Hypothesis can be supported if sig <0.05 and regression coefficient is negative.

Table 6 Hypothesis Test $3 \mathrm{a}$

Hypothesis $\quad$ B $\quad$ Sig

\begin{tabular}{ccc}
\hline H3a. Perceived individual anxiety risk has negative & B,029 & Sig \\
\hline 0,453
\end{tabular}
effect to consumer satisfaction.

The perception of individual anxiety risk is insignificant to consumer repurchase intention. Hence hypothesis $3 \mathrm{a}$ is not supported because it has sig value $>0.05$ is 0.453 and result of coefficient of the regression have positive value. The regression equation can be written as follows:

$\mathrm{K}=3.558+0.029$

Hypothesis $3 \mathrm{~b}$ proposed in this study states that the perception of individual anxiety risk negatively affect the repurchase intention. Hypothesis is said to be supported if sig <0.05 and regression coefficient is negative.

Table 7 Hypothesis Test 3b

Hipotesis

H3b. Perceived individual anxiety risk has negative $0,053 \quad 0,472$ effects to repurchase intention.

The perception of individual anxiety risk is not significant to the repurchase intention. Hence hypothesis $2 \mathrm{~b}$ is supported because it has sig value $<0.05$ that is 0.472 and result of coefficient of the 
regression have positive value. The regression equation can be written as follows:

$$
\mathrm{NP}=7.228+0.053
$$

\section{Influence of Perceived Cost Risk on Customer Satisfaction}

Based on the results of hypothesis testing, H1a indicates that the perception of cost risk is significantly positive to customer satisfaction. This result suggests that the first hypothesis H1a is not supported. This indicates that the higher the perceived risk the higher the consumer satisfaction. Risk perceptions according to Bhatnagar, Misra, \& Rao (2000) are referring to unfair price and time spent in choosing. The reason for this unsupported study is allegedly because of technological developments changing consumer perceptions in online shopping. Consumers do not feel anxious because if the goods are not shipped by the seller then the consumer can file a refund, such as shopee application.

The results of this study are consistent with research conducted by Anwar \& Adidarma (2016) which states that the perception of cost risk does not have a negative effect on customer satisfaction, but different from Yue, Xiangbin, \& Weiguo (2015) perceived cost risk negatively affects consumer satisfaction.

\section{Influence of Perceived Cost Risk on Re-Purchase Intention}

Based on the result of hypothesis testing, $\mathrm{H} 1 \mathrm{~b}$ indicates that perception of cost risk is significant positive to intention of repurchase. This suggests that the hypothesis H1b is not supported. This indicates that the higher the perceived cost risk the higher the purchase intention of fashion products in online shopping in the future. The reason for this unsupported study is allegedly because of technological developments changing consumer perceptions in online shopping. These results indicate that the perception of cost risk does not negatively affect the intentions of consumer repurchase in the fashion products online shopping.

The results of this study are consistent with research by Anwar \& Adidarma (2016) which states that the perception of cost risk does not have a negative effect on the intention of repurchase.

\section{Influence of Perceived Product Riskon Customer Satisfaction}

Based on the results of hypothesis testing, $\mathrm{H} 2 \mathrm{a}$ shows that the perception of product risk negatively affect consumer satisfaction. This suggests that the $\mathrm{H} 2 \mathrm{a}$ hypothesis is supported. These results indicate that the higher the perception of product risks received, the lower the consumer satisfaction in shopping fashion products online.

The results of this study consistent with research Masoud (2013) that the perceived of product risk negatively affec on costumer satisfaction. This result is different from the research of Yue, Xiangbin, \& Weiguo (2015) which become the reference of the researcher, they stated that the perceived of product risk positively influence to consumer satisfaction. This shows that the quality, value and performance of a product is very important for customer satisfaction.

\section{Influence of Perceived Product Risk on Rw-Purchase Intention}

Based on statistical test results, $\mathrm{H} 2 \mathrm{~b}$ indicates that the perception of product risk significantly negatively affect the intention of repurchase. This states that $\mathrm{H} 2 \mathrm{~b}$ is supported. This indicates the higher the perception of product risk received, the lower the possibility for consumers to decide to buy back in the future.

The result of this research is consistent with Masoud's (2013) research which stated that the perceived product risk has negative effects on repurchase intention. This result different from Yue, Xiangbin, \& Weiguo's (2015) research which states that the perceived of product risk hapositively affects on repurchase intention.

\section{Influence of Perceived Individual Risk on Customer Satisfaction}

Based on the results of hypothesis testing, H3a indicates that the Perceived of individual anxiety risk does not have negative effect on costumer satisfaction. This states that $\mathrm{H} 3 \mathrm{a}$ is not supported.

The reason this research is not supported is to be suspected that the consumer has been well acquainted with the seller's reputation from a high rating based on other consumer ratings. In addition each customer has different experience in online shopping. So the perception of individual anxiety risk does not have negative effect on consumer satisfaction. The results of this study is consistent with the study of Anwar \& 
Adidarma (2016) which states that the perception of individual anxiety risk does not have negative effect on consumer satisfaction and Gunawan \& Ayuningtiyas (2018).

Influence of Perceived Individual Risk on RePurchase Intention

Based on the results of hypothesis testing, $\mathrm{H} 3 \mathrm{~b}$ shows that the perception of product risk does not havenegative effect on repurchase intention. This states that $\mathrm{H} 3 \mathrm{~b}$ is not supported.

The reason for this unsupported study is that it is presumed that every consumer who is shopping online has a different experience, the consumer does not have excessive anxiety about the product being accepted because the consumer has been in good standing and is well acquainted with the reputation of the online store. So the perception of individual anxiety risk does not have negative effect on repurchase intention. The results of this study are consistent with the research of Anwar \& Adidarma (2016) which states that the perception of individual anxiety risk does not have negative effect on repurchase intention.

\section{Conclusion}

This study aims to determine the effect of perceived risk perception on consumer behavior in the online purchase of fashion products. The number of samples used is 200 respondents, it can be concluded as follows: The perception of cost risk has a significant value but does not have a negative effect on customer satisfaction. Perception of cost risk has a significant value below 0.005 but does not have a negative effect on re-purchase intention. Perceived product risk has negative effect on consumer satisfaction. This shows that the quality, value and performance of a product is very important for consumer satisfaction. Perceived product risk has negative effect on repurchase intention. Perceived individual risk do not have negative effect on consumer satisfaction and repurchase intentions. This shows the high perceptions of individual anxiety risk perceptions that consumers feel does not affect the level of satisfaction and intention to buy back fashion products online in the future.

The authors found several limitations in this study. Some of the limitations are as follows: This study only took samples of accounting students in Batam universities. This study uses the revelation of a past questionnaire, which is not up to date.

Based on the limitations of the problems described above, there are several suggestions for further research as follows: Extending the sample, not only students but workers who are in the field of accounting. Use the questionnaire statement more up to date in accordance with technological developments.

\section{References}

Ajzen, I. (1991). The theory of planned behaviour. Organizational behaviour and human decision proceses, 50 (2), 179-211.

Anwar, R., \& Adidarma, W. (2016). Pengaruh Kepercayaan dan Risiko pada Minat Beli Belanja Online. Jurnal Manajemen dan Bisnis Sriwijaya, 14(2).

Bauer, R. A. (1960). Consumer behaviour as risk taking. Dynamic marketing for a Changing world, 398.

Bhatnagar, A., Misra, S., \& Rao, H. R. (2000). On risk, convenience, and internet shopping behaviour. Communications of the ACM, 43(11), 98-105.

East, R., Wright, M., \& Vanhuele, M. (2013). Consumer Behaviour: Application in Marketing (2nd Edition). Los Angles: Sage.

Gefen, D. (2000). E-commerce: the role of familiarity and trust. Omega, 28(6). 725-737.

Ghozali. (2012). Aplikasi Analisis Multivariate dg Program IBM SPSS 20.

Ghozali, I. (2001). Aplikasi Analisis Multivariat dengan program SPSS, BY UNDIP SEMARANG.

Ghozali, I. (2012). Aplikasi Analisis Multivariate dengan program IBM SPSS 20. Semarang: Universitas Diponegoro.

Gunawan, H., \& Ayuningtiyas, K. (2018). Pengaruh Kepercayaan, Kemudahan dan Kualitas Informasi terhadap Keputusan Pembelian Daring di Aplikasi Bukalapak pada Mahasiswa Politeknik Negeri Batam. Journal of Applied Business Administration, 2(1), 152-165.

Hsu, S.-H., \& Bayarsaikhan, B.-E. M. (2012). Factors Influencing on Online Shopping Attitude and Intention of Mongolian Consumers.

Hu, Y., \& Xie, Y. (2014). e-Retail Market Charasteristics: Evidence from Comparisons with USA, UK, India and China, in Watada, Spinger New York, New York, 141-149.

Jacoby, J., \& Kaplan, L. B. (1972). The components of perceived risk. Advances in consumer research, 3(3), 382-383.

Javadi, M. H., Dolatabadi, H. R., Nourbakhsh, M., \& Asadollahi, A. R. (2012). An Analyzsis of Factors Affecting on Online 
Shopping Behaviour of Consumer. International Journal of Marketing Studies, 4(5), 81-98.

Jogiyanto. (2011). Konsep dan Aplikasi Structural Equation Modeling berbasis varian dalam penelitian bisnis. Yogyakarta: UPP STIM YKPN.

Kazakeviciute, A., \& Banyte, J. (2012). The Relationship of Consumers Perceived Hedonic Value and Behaviour. [Articel]. Inzinerine Ekonomika-Engineering Economics, 23(5), 532-540.

Kwak, H., Fox, R. J., \& Zinkhan, G. M. (2002). What products ca be succesfully promoted and sold via the internet? Journal of advertising research, 42(1), 23-38.

Lim, N. (2003). Consumers' perceived risk: sources versus consequences. Electronic Commerce Research and Appliacation, 2(3), 216-228.

Masoud, E. Y. (2013). The Effect of Perceived Risk on Online Shopping in Jourdan. European Journal of Business and Management.

Monsuwe, T. P., Dellaert, B., \& Ruyter, K. (2004). What Drives Consumers to Shop Online? A Literatur Review. International Journal of Service Industry Management, Vol. 15 No. 1, 102-121.

Naiyi, Y. E. (2004). Dimensions of Consumers' Perceived Risk in Online Shopping. Journal of Electronic Science and Technology of China, Vol. 2, No. 3.

Narayandas, D. (2005). Building loyalty in business markets. Harvard Business Review, 83(9), 131-139.

Park, C. H., \& Kim, Y. G. (2003). Identifying key factors affecting consumer purchase behaviour in an online shopping context. International Journal of Retail \& Distribution Management, 31(1), 16-29.

Priansa, D. J. (2017). Perilaku Konsumen dalam Persaingan Bisnis Kontemporer. Alfabeta.

Roscoe, J. T. (1975). Fundamental research statistics for the behavioral sciences. New York: Holt, Rinehart and Winston.

Schiffman, L. G., \& Wisenblit, J. (2015). Consumer Behaviour. 11th ed.New Jersey: Pretince Hall.

Shim, S., \& Mahoney, M. Y. (1992). Differentiation of Satisfied Users and Dissastified Users of In-Home Electronic Shopping Mode: An Exploratory Study way, 5. 193.

Sugiyono. (2013). Metode Penelitian Kualitatif, Kuantitatif dan $R \& D$. Alfabeta.

Verhagen, T., \& Van Dolen, W. (2011). The Influence of Online Store Beliefs on Consumer Online Impulse Buying: A model and empirical application. Information \& Management, 48(8), 320-327.

Wang, C. (2016). Examining hedonic and utilitarian motivation for $\mathrm{m}$-commerce fashion retail app engagement. Journal of
Fashion Marketing and Management: An International Journal Vol 22.

Yan, X., \& Dai, S. (2009). Consumer's Online Shopping Influence Factors and Decision-Making Model. Value Creation in EBusiness Management, 89-102.

Yue, C., Xiangbin, Y., \& Weiguo, F. (2015). Examining the Effects of Decomposed Perceived Risk on Consumen Online Shopping Behaviour: a Field Studi in China. Engineering Economics, 315-326. 